\title{
PROMOTING INNOVATION AND HIGH-TECH ENTREPRENEURSHIP IN HISTORICALLY BLACK COLLEGES AND UNIVERSITIES: AN EXPLORATORY RESEARCH
}

\author{
Bivek Adhikari, Bethune Cookman University, bivek.adhikari@students.cookman.edu \\ Alexis Bliese, Bethune Cookman University, alexis.bliese@students.cookman.edu \\ Elon Davis, Bethune Cookman University, elon.davis@students.cookman.edu \\ Leila Halawi, Bethune Cookman University, halawil@cookman.edu
}

\begin{abstract}
This study explores the current state of innovation and high-tech entrepreneurial initiatives in Historically Black Colleges and Universities (HBCUs). Previous research showed that institutions' environment, faculty empowerment, organizational trust, early stage capital, innovation centers and innovative teaching practice had a major effect to support innovation and foster tech-entrepreneurship. We present our conceptual model. The final section explains the current state of research and implications for future research are discussed.
\end{abstract}

Keywords: HBCU, Innovation, Innovation in Universities, Historically Black College and University, high-tech entrepreneurship, University innovation, Incubator.

\section{INTRODUCTION}

Historically Black Colleges and Universities are institutions that were established before 1964 expressly to educate African -Americans [19]. Though the advertised reason for the existence of the HBCUs is to enable African American students to experience greater success, Lee and Jang argue that HBCUs were originally created to deter attendance of African Americans at White colleges and universities. Despite the suppressive intentions behind this humble beginning, HBCUs have endured severe adverse conditions and showed the perseverance to develop into an imperative institution in the mosaic of U.S. higher education [25]. Currently, there are 105 HBCUs located in 20 states, District of Columbia, and the U.S. Virgin Islands that serve more than 300,000 undergraduate and graduate students [27].

Prior research shows that continuous innovation and development of capable and creative workforces contributes to nation's prosperity. Knowledge and learning is core to the innovation process [2]. Research and development universities are a key component of innovation for any country [2]. Research universities in particular contribute significantly to the development of indigenous technological innovation [2]. Over half of the US economic growth comes from science and technological innovation [2].

University led innovation is a major innovation pipeline for the country [14]. Universities are one among those few places where game-changing- disruptive and radical innovation takes place. Despite university research activity being a foundation for many of the most important technological advancement in the U.S., many ideas are left unexplored on the universities laboratory's shelves today [14]. Therefore, there exists a tremendous opportunity for the economic and social impact yet to be made through the universities led innovation activities [14].

One of those universities though, which have not received a significant attention in the field of high-tech innovation are HBCUs. In spite of the fact that the HBCUs fuel a disproportionately large number of African American science, technology, engineering and mathematics (STEM) brain power for the country, HBCU's have not been able to focus on innovation [15]. Research on HBCU's has suggested that new visions and innovation are prerequisite for the survival of these institutions [8][11]. However, Innovation has not been a significant focus of research at HBCUs [18].

There are 43.9 million African-Americans in the U.S. making up 13.6\% of the total U.S. population [36]. 


\section{Issues in Information Systems \\ Volume 15, Issue I, pp. 303-311, 2014}

However, only 1 percent of the venture capital-backed founders in the U.S. are African American. The black tech employees' percentage in Silicon Valley decreased from 2.8 percent to 2.3 percent [17]. Black Entertainment Television (BET) explicitly reports that Black consumers are very tech-savvy and techrelated goods comprise the majority of their purchases [22]. African American students are less likely to graduate from college than their White peers; national graduation rate of African American students are $20 \%$ lower than White students [5]. At the same time, there has been a continuous decrement in the number of computer science graduates from HBCUs [28]. HBCUs' greatest decline in the percentage of graduates lies in the field of computer science when compared to non-HBCUs [28].

This paper explores the potential role of HBCU campuses as innovation catalysts for Black entrepreneurs and relates that to tech-innovators.

The paper begins by reviewing the relevant literature in the area of innovation. We then present our conceptual model. The final section explains the current state of research and implications of our preliminary conclusions.

\section{REVIEW OF LITERATURE}

The Literature review provides the background to the issues and factors surrounding tech-innovation in universities and the current status of innovation in HBCU campuses

\section{Innovation Defined}

Prior research has not reached a consensus when it comes to defining innovation [12]. Different organizations define innovation differently and the way organizations define innovation affects the way organization operates [12].

While many definitions of innovation stress the economic value, most agree that innovation relates to novelty and newness [12]. Zaltman et al. [38] defined innovation from the process of adoption's viewpoint; they stated innovation as a new idea perceived to be new by pertinent adoption groups. Nohria and Gulati [26] emphasize the internal processes and structure in their version of the definition of innovation. The European Commission Green paper [7] on innovation perceives innovation from macro landscape bringing up the newness in social and economic spheres. While most agree that innovation relates to newness and novelty, Rogers [30] addresses the diffusion of existing knowledge as an important notion in innovation. Rogers [30] supports his notion of diffusion of existing knowledge as innovative behavior by reflecting on the technology transfer between companies and market spin-offs.

For the purpose of this paper, while agreeing to Roger's [31] definition of innovation involving both, the creation of new knowledge and the diffusion of existing knowledge, we add Nohria and Gulati's [26] notion that innovation can happen from internal processes level to the diffusion level and should play a major role in contributing to a company bottom-line [12].

\section{High-Tech Innovation}

Technology is defined as a tool to convert inputs into a product or a tool to attain goals [1]. Aleixo and Tenera [1] define technology as a complete package of hardware, software, brainware and technology support. Organization for economic Co-operation and Development (OECD) statistics [39] defines technology innovation to include new products and processes, and significant technological changes of products and processes. Technology innovation is further divided into (regular) tech-innovation and hightech innovation [1].

High technology is a technology core that changes the structure and organization of the technology support net [1]. Technology support net is the most important part of technology among the four components of the technology package defined by Aleixo \& Tenera [1]. Technology support net is a network of physical, informational and socioeconomic relationships that enable the proper use and functioning of a given 


\section{Issues in Information Systems \\ Volume 15, Issue I, pp. 303-311, 2014}

technology [1]. There is a fine line of distinction between the high technology (High-tech) and the (regular) technology. The regular technology core changes the efficiency of the flow of the technology support net, whereas, the high-tech changes the structure and organization of the technology support net [1].

High-tech innovations, among many other types of innovation, with great commercial value have become one of the driving forces for global welfare [30]. Minola and Giorgino [23] state that new technology firms are the major prospect for a nation to gain the competitive edge, increase employment opportunities, and develop the nation's economy via commercial success as these new technology- based firms continue to become a major source of radical innovation. Commercial success of the innovation is measured by various financial tools such as return on sales ratio, return on investment ratio and others [30]. Researchers have cited that education and training is an important source for innovation and that the education and training contributes to speeding up the technology transfer process of converting the results of research into marketable products and services [32].

\section{University Led High-Tech Innovation}

Previous research has continuously stated that universities have unique strength and agreed that they play an important role in the process of innovation [2][13]. With the explosive growth of high-tech products and emerging companies within the high-tech industry, universities are increasingly becoming more important players in the process of innovation, invention and commercialization [16]. As mentioned by Luger and Goldstein [21], Universities have unique advantages that include:

a) Concentration of technical knowledge and expertise

b) Scientific and nonpartisan nature making universities credible

c) Inexpensive pool of talent

Leveraging the benefits above, researchers have claimed that many universities today have dramatically raised entrepreneurial activity in the form of patenting, licensing, joint research activities and creating spinoff companies [34]. Research has shown that scholarly interest in academic entrepreneurship directly corresponds with the entrepreneurship activities in universities [34]. More specifically, St. Clair [35] has found that business majors, particularly in the university system, have a desire to gain more knowledge on what it takes to get their own innovative ideas to the next level. He also states that one of the main reasons students decide to major in business is to be able to promote innovative ideas and form their own business model around those concepts. The ultimate goal is to be the business leaders of the future [35]. If students cannot receive the knowledge needed to be entrepreneurial while in college, they are less likely to receive the information in such a structured format elsewhere. St. Clair [35] further states that business schools currently offer different courses on the techniques and theories of innovation and organizational change, but they do not commonly relate it to how one can pursue their own ideas effectively.

\section{HBCUs and High-Tech Innovation}

When it comes to innovation in the Historically Black Colleges and Universities (HBCUs), research shows that innovation has not been a significant focus [19].

The US government designated the name HBCU in 1965 to classify and support 100 schools in the U.S. [9]. HBCUs make up 3 percent of all higher education institutions enrolling about $14 \%$ of African American undergraduate students throughout the nation. Despite enrolling just $14 \%$ percent, only $28 \%$ of all African American students complete their studies [4][10]. There is a significant amount of research being done to bring forward various issues of HBCUs and their importance. Most research agrees that HBCUs play an important role to train black professionals. Over $50 \%$ of all black professionals come from HBCU's [18]. Moreover, 9 out of 10 top college producers of successful black PhD applicants are HBCU's [18]. HBCUs are especially known for preparing African-Americans to enter math and science oriented fields and $50 \%$ of all African- American engineers are graduates of HBCU's [18]. 


\section{Issues in Information Systems \\ Volume 15, Issue I, pp. 303-311, 2014}

Scholars have stated that the place-based knowledge contributes significantly to the overall structure of an effective innovation system, which then adds to the case that universities play an essential role to facilitate the intersection of ideas [2]. Based on Allison \& Eversole's [2] discussion about the implication of the university's place-based knowledge system and HBCU's unique offerings to African-Americans, we observe that HBCU campuses like other knowledge institutions can be seen as critical instrument for innovation and development of black professionals.

\section{Support for Innovation}

Lee and Jang [19] conducted a study to explore the support for innovation in HBCUs. They examined the HBCUs' disposition towards change, empowerment, overall state of the organizational trust, and the state of conflict and support for innovation. They used a theoretical model to explain the current state of innovation and the support for innovation. In their model, the dependent variable was the support for innovation, intervening variables included disposition toward change, empowerment, and organizational trust, while the independent variables included organizational conflict and demographic variables. They targeted about 103 HBCU's and the model resulted in six hypotheses that were tested via factor analysis, multiple regression and structural equation modeling. They concluded that HBCU's have low organizational trust and support for innovation and need to empower their faculty to support innovation. Additionally, they found that there is high level of interpersonal conflict between faculty and administrators, which explains the lower level of support for innovation. They also found that negative factors such as low salary, heavy teaching loads, vertical leadership, financial instability, leadership challenges and other organizational policies and structure have been hindering HBCU's ability to innovate. So when it comes to higher education, Lee and Jang have established that faculty members are key individuals in innovation and innovation related processes. Which then lead them to presume that the innovative capacity of an organization relies heavily upon the faculty members' perceptions of innovation. Our conceptual model for this study is a modified version of Lee and Jang's model.

In addition to organizational trust and the role of faculty in innovation, studies have shown that early stage capital and availability of programs to enable university innovators, entrepreneurs, and investors to connect with each other is important [14]. Furthermore, young and innovative business organizations, such as techstartups, require adequate context and efficient and effective tools to survive and develop [23]. Eckert [6] also emphasized that key stakeholders of an organization must work together to exploit an industry's ability to achieve innovation, both for new and existing technologies. Minola and Giorgino [23] added that globalization, technological evolution, growing complexity of market, dynamic and turbulent market with foreign competition were some of the challenges of today's economy for the technology companies and therefore, these technology- based companies will require a greater flexibility and courage along with efficient and effective tools to compete effectively.

Lieberson and Mikelson [20] made a strong point that new ideas are embedded in the existing thought structure of a society. They [20] also stated that institutional forces such as organizational structure, patronage and critics affect the innovation process. When it comes to HBCUs, these institutions have constantly faced challenges in their organizational structure and other institutional forces including leadership, low retention rates of students and financial instability [11]. The fact that 12 HBCUs have closed in the past 20 years shows HBCUs' current downfall [37]. Prior research shows that organization members' openness and support for innovation significantly mediates organizations' ability to innovate [3]. Researchers have explicitly summarized that the more an organization member believes in their organization's support for innovation, the more innovative they tend to be [33].

\section{MIT, UCSD and USC innovation hub}

The case studies below cover a wide array of the university led high-tech entrepreneurship initiatives at PWIs and HBCUs in the United States.

Incubators, in entrepreneurship, are entities sponsored and run by private companies, universities, public institutions or a mix of these bodies to help young and promising small businesses grow and succeed 
(entrepreneur.com). National Business Incubation Association (NBIA) supports business incubation programs to its 1,900 members in over 60 countries. There are approximately 900 business incubators in the United States.

Not all business incubators are alike; they differ in size, specialization area, location, growth stage as well as other criteria [40]. Some incubators are heavily funded and some lack in capital. Companies spend an average of two years at an incubator before they graduate and run their businesses on their own. During their stay at an incubator, companies share telephone, secretarial support, office equipment, and other operational and production overheads [40].

Holly [14] pinpointed universities that received assistance through a major gift or local funding that went to create innovation centers with great success stories. The Massachusetts Institute of Technology's (MIT) Deshpande Center for Technological Innovation and University of California at San Diego's (UCSD) von Liebig Center with less than a $\$ 10$ million dollar university investment have contributed to advance 26 startups that went to raise a total of $\$ 160$ million in outside investments [14].

The MIT Despande Center for Technological Innovation created in 2002 has provided a total of $\$ 13,000,000$ in grants alone to 100 MIT research projects since its inception. The center recently announced in October 2013 that it is awarding \$949,764 in grants to 12 MIT early-stage technologies research teams. These projects carry potential to make significant impact in the field of cancer treatment, disease monitoring, nano electronics and other high-tech projects.

Holly also related MIT and UCSD stories to University of Southern California's (USC) Stevens Institute for innovation, which is a 2-year-old innovation center with a \$22 million gift investment. Holly [14] mentioned how the funding has been used to reengineer business development, traditional technology transfer and has been utilized to support student innovators to create a university-wide culture of innovation.

\section{Comparing PWIs' and HBCUs' innovation initiatives in Florida}

Floridians schools, mostly Predominantly White Institutions, have also embraced innovation as a critical component to university education. University of Florida (UF), University of Central Florida (UCF), and Florida State University have tapped-in to create a University innovation center to promote entrepreneurship and innovation in college campuses. University of Florida's Innovation Hub has contributed to create 250 jobs in just 20 months of its launch [24]. With $\$ 8.2$ million grant from U.S Economic Development Administration and a $\$ 5$ million dollar contribution from UF, the incubator is located very close to the college campus [24]. UCF also has an outstanding incubation program with 8 incubators at and around the central Florida area. Since its inception in the October of 1999, the UCF business incubation program has assisted to sustain over 3,300 jobs with an average salary of $\$ 67,000$ helping companies to create a regional output of more than $\$ 620$ million. Meanwhile, the Floridians HBCUs have entirely different story to share.

There are four HBCU's -- Bethune-Cookman University (BCU), Florida Agricultural and Mechanical University (FAMU), Florida Memorial University and Edward Waters College -- in the state of Florida. All four institutions, including FAMU - largest HBCU in the United States and a public institution with over 12,000 students do not have an innovation center or an incubation program. All four institutions, however, have signed an agreement with Small Business Administration (SBA).FAMU, in particular, have a partnership program with SBA and in-house SBDC program that allows many features of an incubator.

\section{RESEARCH METHODOLOGY}

\section{Research Questions}

This study seeks to research the following questions. 


\section{Issues in Information Systems \\ Volume 15, Issue I, pp. 303-311, 2014}

1. Why is the African-American community not producing a significant number of tech-entrepreneurs?

2. Does the lack of resources, the absence of empowerment, resistance to change and organizational trust on HBCU campuses contribute to the scarcity of tech-entrepreneurship pursued on Black campuses?

3. Do demographic variables that include age, gender, race and education have a direct effect on support for innovation on HBCU campuses?

4. Does the level of intrapersonal conflict between faculty and administrators have a direct effect on the support for innovation on HBCU campuses?

We adopted a modified version of Lee and Jang [19] analytical model. Our conceptual model (Figure 1) integrates resistance to change, organizational trust, empowerment and lack of resources. The independent variables are conflict between faculty and administrators, academic environment, distribution of funding, priorities of education and demographics such as age, race, gender, and education.

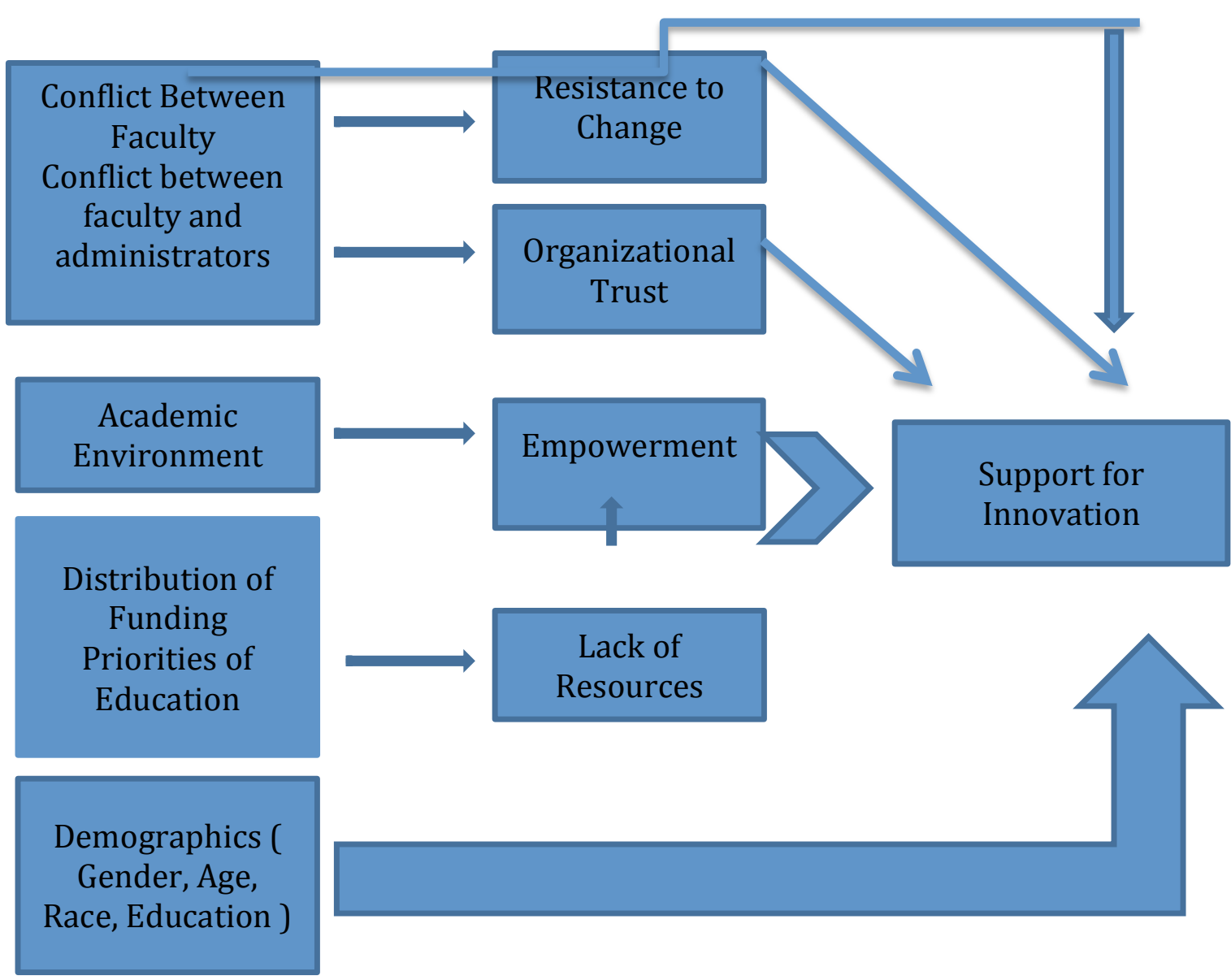

Figure 1: Conceptual Model 


\section{Hypothesis}

H1: Resistance to change, organizational trust, faculty empowerment and lack of resources are directly related to the discouragement and hindrances of high tech-entrepreneurship ambitions and high-tech innovation on HBCU campuses.

We will adopt a survey methodology and will use a questionnaire based data collection technique. The theoretical constructs will be operationalized and measured using items derived from Lee and Jang's validated surveys [19].

The population that is of interest for this study will include 200 students and faculty from a historically black university. Partial least squares using Smart PLS will be used to analyze the data and test the hypothesis in a future study.

\section{CONCLUSIONS}

There exist major challenges, on top of the regular constraints, for a young African American student to pursue a college degree, let alone an entrepreneurial career. However, pursuing an entrepreneurial venture might be a method to circumvent the deficient background and innovation might be the key to success. As stated by Ozgen and Minsky [29] opportunity recognition is a crucial step in the entrepreneurial process and the fact that there is a huge gap between the African American Tech consumers and Tech producers might be the window of opportunity for young African American Entrepreneurs.

This is a research in progress. To complete our analysis, a Partial Least Squares and structural equation modeling (SEM) tool (Smart-PLS 2.0 M3) will be used. SEM permits a simultaneous assessment of the structural component (path model) and measurement component (factor model) in the one model. Similar to LISREL and associated structural equation approaches, PLS presents the benefit of permitting the complete research model to be tested just once.

The results of this study should provide useful guidelines, motivation and framework for HBCU leaders to pilot an incubation program and promote innovation. Second, based on findings of this research, we believe that exploration of the ways to develop an entrepreneurial environment in HBCU campuses and discovery of an ideal innovation center model for HBCUs is a worthwhile extension of this research and will spur innovation at $\mathrm{HBCU}$ campuses.

\section{REFERENCES}

1.Aleixo, G., \& Tenera, A. (2009). New Product development Process on High-Tech Innovation Life Cycle. World Academy of Science, Engineering and Technology, 58, 794-800.

2.Allison, J., \& Eversole, R. (2008). A new direction for regional university campuses: catalyzing innovation in place. Innovation: The European Journal Of Social Sciences, 21(2), 95-109. doi:10.1080/13511610802214321 3.Armenakis, A. A., Harris, S. G., \& Mossholder, K. W. (1993). Creating readiness for organizational change. Human Relations, 46(6), 681-703. doi:10.1177/001872679304600601

4.Black or African American Populations. (2013, July 2). Centers for Disease Control and Prevention.

Retrieved October 15, 2013, from http://www.cdc.gov/minorityhealth/populations/REMP/black.html 5.Boyraz, G., Horne, S. G., Owens, A. C., \& Armstrong, A. P. (2013). Academic achievement and college persistence of African American students with trauma exposure. Journal of Counseling Psychology, 60(4), 582-592. doi: $10.1037 / \mathrm{a} 0033672$

6.Eckert, P. (2010). High-tech innovation: Promoting space industry growth. The Psychologist-Manager Journal, 13(2), 86-92. doi:10.1080/10887151003761283 
7.European Commission. (1995). Green Paper on Innovation. http://europa.eu/documents/comm/green_papers/pdf/com95_688_en.pdf 8. Fields, C. D. (2001). Parting words. Black Issues in Higher Education, 18(9), 22-27. 9. Fogle, C. (2012). Employers' Perceptions of Business Graduates from Historically Black Colleges and Universities. Global Education Journal, (1), 11-70.

10. Gasman, M., Baez, B., Drezner, N. D., Sedgwick, K. V., Tudico, C., \& Schmid, J. M. (2007).

Historically black colleges and univerisites: Recent trends. Academe, 93(1), 69-78.

11.Gregory, S. T. (2003, April). Negotiating culture: Faculty roles and responsibilities in HBCU. Paper presented at the annual meeting of the American Educational Research Association, Chicago, IL. Retrieved from ERIC database. (ED478597)

12. Goswami, S., \& Mathew, M. (2005). Definition Of Innovation Revisited: An Empirical Study On Indian Information Technology Industry. International Journal of Innovation Management, 9(3), 371-383. 13.Hasenauer, R, Filo, P. \& Stori, H (2012). The marketing of high-tech innovations: research and teaching as a multidisciplinary communication task. M-Sphere Dubrovnik 2012: 1st International MSphere conference - Zagreb: M-Sphere - Association for promotion of multidisciplinarity in science and business, 2012. p. 50. ISBN 978-953-99762-9-1, abstract available from: http://issuu.com/tvranes/docs/book_of_abstracts_m-sphere_conference_2012 14. Holly, K. (2012, October 1). Innovation Model Program for Accelerating the Commercialization of Technologies. IMPACT: Retrieved December 8, 2013, from http://stevens.usc.edu/docs/IMPACT\%20Initiative\%20Whitepaper.pdf

15. Jackson, D. (2013). A Balancing Act: Impacting and Initiating the Success of African American Female Community College Transfer Students in STEM into the HBCU Environment. Journal of Negro Education, 82(3), 255-271

16. Kartus, R., \& Kukrus, A. (2013). Innovation, product development and patents at universities. Estonian Journal Of Engineering, 19(1), 4-17. doi:10.3176/eng.2013.1.02

17. Klein, K. (2013, May 30). Education, Mentors, Money: How to Boost Black Tech Entrepreneurs. Bloomberg Business Week. Retrieved October 16, 2013, from http://www.businessweek.com/articles/201305-30/education-mentors-money-how-to-boost-black-tech-entrepreneurs 18. Lee, C. (2009). "Mind the Gap": Investigating the income gap between black graduates of HBCUs and non-HBCUS. Conference Papers -- American Sociological Association, 929.

19. Lee, S., \& Jang, D. (2012). Support for Innovation in Historically Black Colleges and Universities: Exploring Associations with Disposition Toward Change, Empowerment, and Organizational Trust. Journal of Black Studies, 43(8), 912-935. doi:10.1177/0021934712463236

20. Lieberson, S., \& Mikelson, K. S. (1995). Distinctive African American names: An Experimental Historical, and Linguistic Analysis of Analysis of Innovation. American Sociological Review, 60(6), 928946

21. Luger, M. I. \& Goldstein, H. A. (1997) What is the role of public universities in regional economic development?,in: R. D. Bingham \& R. Mier (Eds) Dilemmas of Urban Economic Development: Issues in Theory and Practice, pp. 104-134 (Thousand Oaks, CA: Sage).

22. Miller, R. K., \& Washington, K. (2013). Part VI: Ethnic: Chapter 32: African-American

Consumers. In, Consumer Behavior (pp. 213-218). Richard K. Miller \& Associates.

23.Minola, T. \& Giorgino, M. (2008). Who's going to provide the funding for high tech start-ups? A model for the analysis of determinants with a fuzzy approach. $R \& D$ Management, 38 (3), 335-351. 24. Moran, C. (2013, August 26). UF: Innovation Hub spawns 250 jobs in just 20 months. News. Retrieved December 9, 2013, from http://news.ufl.edu/2013/08/26/hub-impact/ 25.Nichols, J. C. (2004). Unique Characteristics, leadership styles, and management of historically Black colleges and universities. Innovative Higher Education, 28(3), 219-229, doi: 10:1023/B:IHIE.00000151109.49156.fb.

26. Nohria, N and R Gulati (1996). Is slack good or bad for innovation? Academy of Management Journal, 39(5), 1245-1264.

27. Obama, B. H. (2010). Executive Order 13532--Promoting Excellence, Innovation, and Sustainability at Historically Black Colleges and Universities. Daily Compilation of Presidential Documents, 1-4. 


\section{Issues in Information Systems \\ Volume 15, Issue I, pp. 303-311, 2014}

28. Owens, E. W., Shelton, A. J., Bloom, C. M., \& Kenyatta Cavil, J. J. (2012). The Significance of HBCUs to the Production of STEM Graduates: Answering the Call. Educational Foundations, 26(3/4), 3347.

29. Ozgen, E., \& Minsky, B. D. (2013). Why some college students engage in entrepreneurial activities while others do not Journal of Entrepreneurship Education, 1645-58.

30. Rainer, Peter, Herbert, \& Hasanauer. (2012). The High-Tech Innovation: Research and Teaching as a Multidisciplinary Communication Task.

31. Rogers, M (1998). Definition and Measurement of Innovation. Melbourne Institute Working Paper No. $10 / 19$.

32. Schultea, P., Živkovićb, D., Graefc, M., Vadnjald, J., Triscae, G., Mihajlovićb, I., \& ... Tantauj, A. (2013). Resita Network - Academic Entrepreneurship And Innovation Network Of South Eastern European Universities: An Example Of Successful Networking In Entrepreneurship And Innovation At Academic Level. Serbian Journal Of Management, 8(1), 117-130. Doi:10.5937/Sjm8-3360

33. Scott, S. G., \& Bruce, R. A. (1994). Determinants of innovative behavior: A path model of individual innovation in the workplace. Academy of Management Jour- nal, 37(3), 580-607. doi:10.2307/256701 34. Siegel, D. S., Wright, M., \& Lockett, A. (2007). The rise of entrepreneurial activity at universities: organizational and societal implications. Industrial \& Corporate Change, 16(4), 489-504.

35. St. Clair, D. (2008). A study of innovation in collegiate business education

(Doctoral dissertation, ProQuest LLC, Ann Arbor). Retrieved April 14, 2014

36. Venture Capital Human Capital Report - Gender, Race, Age, Education Demographics on VC

Backed Company Founders. (2010). CB Insights Blog. Retrieved December 9, 2013, from

http://www.cbinsights.com/blog/venture-capital/venture-capital-human-capital-report-gender-andeducation

37. Willie, C. V., Reddick, R. J., \& Brown, R. (2006). The Black college mystique. Lanham, MD:

Rowman \& Littlefiel

38. Zaltman, G, R Duncan and H Jonny (1973). Innovations and Organizations. New York: John Wiley \& Sons.

39. http://stats.oecd.org/glossary/detail.asp?ID $=2688$

40. http://www.entrepreneur.com/encyclopedia/business-incubator 